\title{
Imaging of Distal Dural Ring Plane and Paraclinoid Internal Carotid Artery Aneurysms with 3D Rotational Angiography
}

\author{
Dongwoo Lee, MD', Tae-Hyung Kim, MD², Bum-Soo Kim, MD², Yeon-Kwon Ihn, MD², \\ Yoo Dong Won, MD², Joonho Chung, MD³, Yong Sam Shin, MD', Kwan Sung Lee, MD
}

Purpose: The distal dural ring (DDR) plane separates the intradural from extradural paraclinoid internal carotid artery (ICA) aneurysm. The purpose of this study was to evaluate the feasibility of the localization of the DDR plane drawn by the bony landmarks in patients with paraclinoid ICA aneurysms at $3 \mathrm{D}$ rotational angiography (3DRA).

Materials and Methods: 13 consecutive patients who underwent a 3DRA for the evaluation of 16 paraclinoid ICA aneurysms were reviewed retrospectively. On a dedicated workstation, multiplanar reconstruction (MPR) image along the virtual plane of DDR was reconstructed from the mask run image of 3DRA. Three bony landmarks were used to locate virtual plane of DDR: tuberculum sellae, inferior root of anterior clinoid process and supero-medial aspect of optic strut. The MPR image was fused with 3D volume-rendered reconstruction image. Medial and posterior inclination angle of virtual plane of DDR was measured. The location of the paraclinoid ICA aneurysm was categorized into indradural, transdural, and extradural.

Results: In all cases, the DDR plane was identified and the relationship between the DDR plane and the paraclinoid ICA aneurysm was successfully determined on fusion image of 3DRA mask and contrast runs by dual volume visualization. The aneurysm locations determined with 3DRA were 8 intradural, 6 transdural and 2 extradural. The medial and posterior inclination angles of DDR plane ranged at 8 to $43^{\circ}$ (mean $17.4^{\circ}$ ), and -2 to $20^{\circ}$ (mean $6.4^{\circ}$ ), respectively.

Conclusion: Localization of the paraclinoid ICA aneurysm in relation to the virtual plane of DDR is feasible with 3DRA and dual volume visualization.

Key Words : Distal Dural Ring; Paraclinoid Aneurysm; 3D Rotational Angiography

'Department of Neurosurgery, Cheju Halla Hospital, Jejudo, Korea; ${ }^{2}$ Department of Radiology, and ${ }^{4}$ Department of Neurosurgery, The Catholic University of Korea, Seoul, Korea; ${ }^{3}$ Department of Neurosurgery, Inha University School of Medicine, Incheon, Korea

Received March 2, 2010;

accepted after revision May 16, 2010.

Correspondence to: Bum-soo Kim, MD, Department of Radiology, Seoul St. Mary's Hospital, The Catholic University of Korea, 505, Banpodong, Seocho-gu, Seoul 137-701, Korea.

Tel. 82-2-2258-6239 Fax. 82-2-599-6771 E-mail: bumrad@catholic.ac.kr

Neurointervention $2010 ; 5: 85-90$ 
The distal dural ring (DDR) plane separates the intradural from extradural paraclinoid internal carotid artery (ICA) aneurysm (1-3). The intradural paraclinoid aneurysm carries a potential risk of subarachnoid hemorrhage (SAH), while the extradural paraclinoid aneurysm has limited or no risk of SAH, thus mostly managed by conservative treatment in asymptomatic patients. The traditional landmarks for discrimination between paraclinoid and cavernous sinus aneurysms are the origin of the ophthalmic artery (4) or bony structures such as optic strut, root of anterior clinoid process and tuberculum sellae $(2,5,6)$. Identification of the DDR plane in relation to these landmarks has been studied by various imaging modalities including angiography (4), CT angiography (5-7), and MRI (812).

During the acquisition of rotational angiography, dual volume of data set can be obtained with double rotation of C-arm; mask run without contrast media followed by the angiographic run with injection of contrast media. The dual volumes of mask and subtracted angiographic data can be displayed on the single task window on workstation, as embedded multiplanar reconstruction, and this dual volume visualization enables evaluation of relationship between the vessels on angiography and anatomic structures such as bony prominences or foramens.

The purpose of this study was to evaluate the feasibility of the localization of the DDR plane drawn by the bony landmarks in patients with paraclinoid ICA aneurysms at 3 dimensional rotational angiography (3DRA) with dual volume visualization.

\section{MATERIALS AND METHODS}

\section{Patients}

13 consecutive patients (4 men, 9 women; age range, 28 67years; mean, 53.1years) who underwent a 3D RA for the evaluation of 16 paraclinoid ICA aneurysms between March 2009 and August 2009 were retrospectively reviewed. Twelve patients had one or two unruptured aneurysms and remaining 1 patient had ruptured one. Three patients had bilateral paraclinoid aneurysms. The size of aneurysms ranged from $2.3 \mathrm{~mm}$ to $12 \mathrm{~mm}$. Seven aneurysms had broad neck, and those were managed by stent-assisted coil embolization.

\section{D rotational angiography with dual volume visual- ization}

Selective internal carotid dual volume angiography was performed on an Axiom Artis Zee Angiography
System (Siemens, Medical Solutions, Forchheim, Germany) with flat panel detector, and dual volume data including mask and angiography images were acquired using Dynavision rotational angiography technology. All data were successively transferred to the Leonardo workstation (Siemens, Erlangen, Germany) via high-speed network, in order to realize the fusion of the vascular and bony images. Visualization of 3D VR angiographic reconstruction images combined with multiplanar reconstruction (MPR) image of mask volume are generated with DynaCT software (Siemens, Erlanger, Germany). Images from the rotational angiography are reconstructed on the Leonardo workstation and are available for assessment in approximately 3 minutes. Image acquisition takes approximately 12 seconds.

To localize virtual plane of DDR from mask run, three bony landmarks were first identified on multiplanar reconstruction images; 1) tuberculum sellae medially, 2) inferior root of anterior clinoid process (ACP) laterally, 3) superior dorsally superio-medial aspect of optic strut (Fig. 1). This MPR image along the virtual plane of DDR was then fused with $3 \mathrm{D}$ volume-rendered reconstruction angiographic image (Fig. 2). To get the virtual plane passing through all these three bony landmarks, three steps were made; 1) locate the central point of sagittal and axial views to the level of ipsilateral tuberculum sellae, 2) sagittal view medial inclined to get the ipsilateral distal ACP in the same plane, 3 ) coronal view inclined posteriorly to get the upper margin of optic strut.

The angle of inclination was measured from the final virtual plane of DDR, in relation to the planum sphenoidale. Distance from the virtual plane of DDR to the origin of ophthalmic artery and that from the aneurysm to ophthalmic artery was measured, respectively. On the basis of the relationship between the aneurysm and virtual plane of DDR, the aneurysms were recorded as intradural, in which the aneurysm was located distal to the DDR; transdural, in which the aneurysm was located on both sides of the DDR; and extradural, in which the aneurysm was located proximal to the DDR.

\section{RESULTS}

In all cases, virtual plane of DDR was identified and the relationship between the DDR and the aneurysm was successfully determined on fusion image of $3 \mathrm{D}$ RA with dual volume visualization. With the virtual plane of DDR on fusion image as reference, location of 


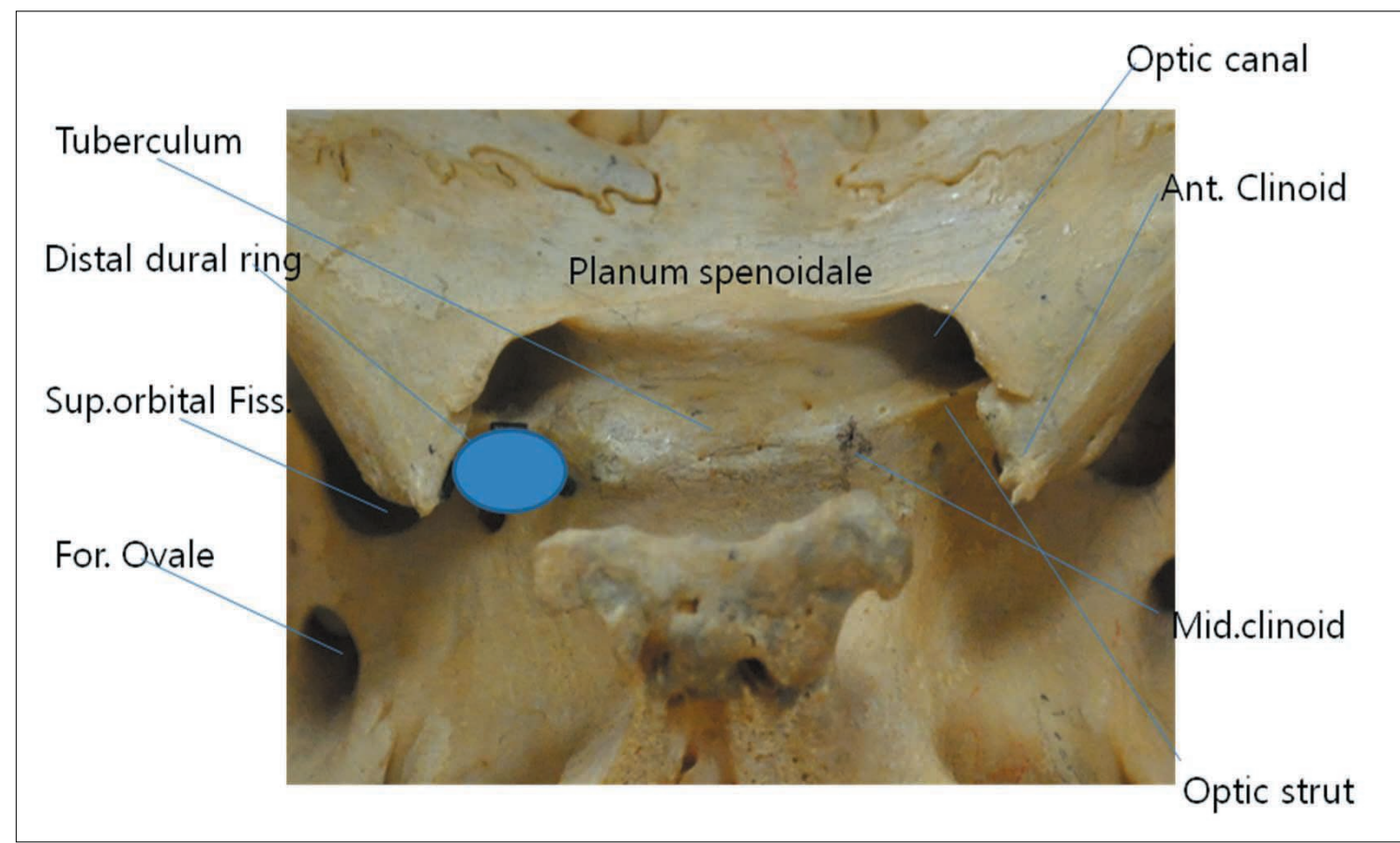

Fig. 1. Photographs presenting superior views of the Distal dural ring (DDR, Blue circle) area in dry skull, showing the relationship of bony landmarks and dural structures.

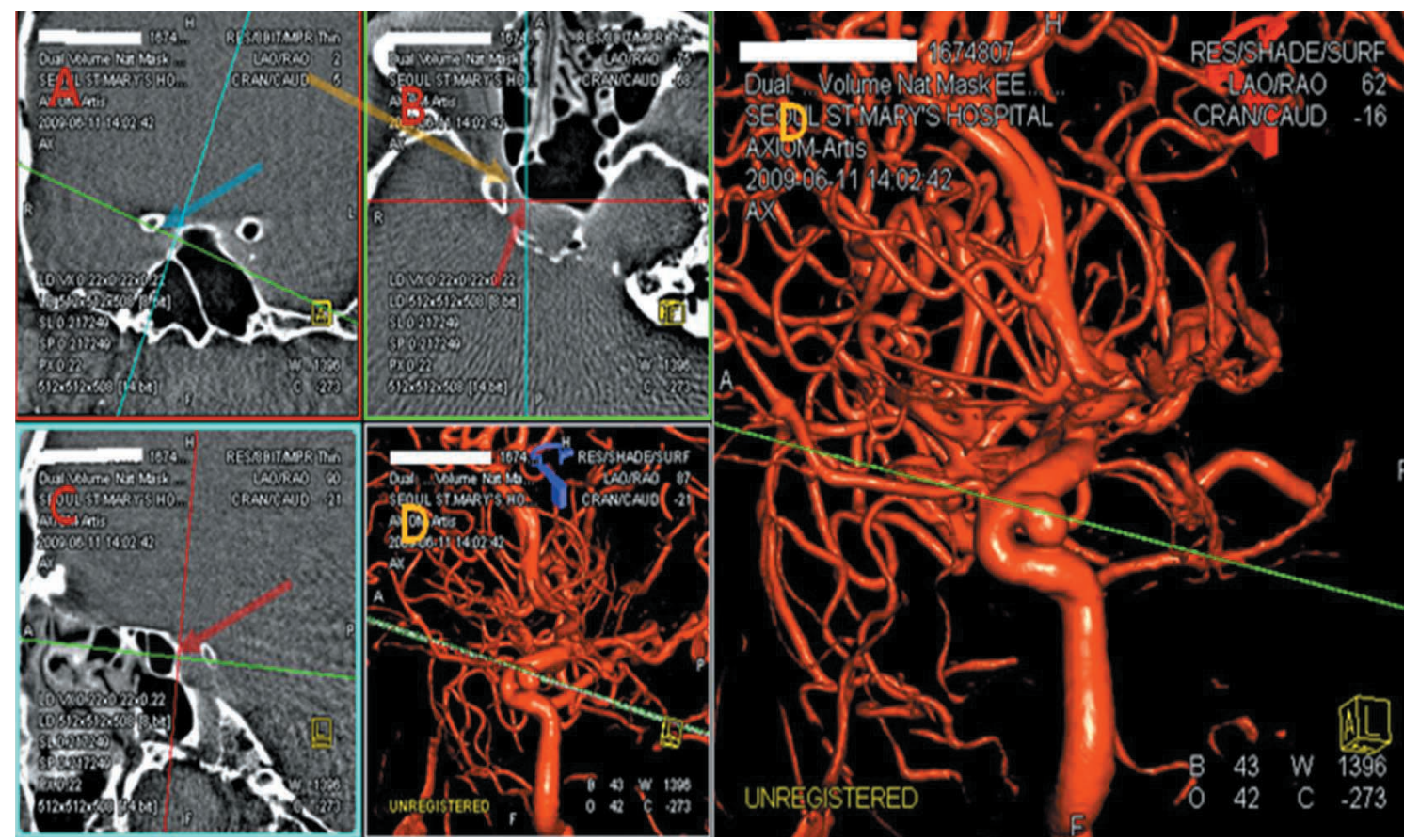

Fig. 2. Localization of multiplanar reconstruction (MPR) image from the mask run image of 3D rotational angiography, along the virtual plane of DDR by three bony landmarks: tuberculum sella, inferior root of anterior clinoid process (ACP), and optic strut.

A. Coronal plane rotated to align inferior root of anterior clinoid process and tuberculum sella.

B. Axial plane rotated to align inferior root of anterior clinoid process and base of tuberculum sella.

C. Sagittal plane to align optic strut.

D. 3D reconstruction image with virtual DDR plane (green line).

Red arrow: tuberculum sellae, Blue arrow: inferior root of ACP, Yellow arrow: optic strut. 
the aneurysm was determined to be intradural in 11 aneurysms, transdural in 3 aneurysms, and extradural in 2 aneurysms.

The measured distance between the origin of ophthalmic artery and the virtual plane of DDR ranged from $-1.39 \mathrm{~mm}$ to $4.33 \mathrm{~mm}$. The measured distance between the aneurysms and the DDR plane ranged $1.92 \mathrm{~mm}$ to $5.93 \mathrm{~mm}$. The mean of medial inclination angle of virtual plane of DDR was $17.4^{\circ}$, and that of posterior inclination angle was $6.4^{\circ}$. The mean distance from virtual plane of DDR to ophthalmic artery was $2.32 \mathrm{~mm}$, and that from virtual plane of DDR to aneurysm was $2.34 \mathrm{~mm}$.

The direction of the aneurysm sac from the ICA was posterior in 8 aneurysms, medial in 7 aneurysms, and anterolateral in 1 aneurysm. In 2 cases (12.5\%) in our series, ophthalmic artery arises proximal to virtual plane of DDR, exactly at the DDR in 1 case, and distal to the DDR in 13 cases.

\section{DISCUSSION}

In our series of 13 consecutive patients, virtual plane of DDR could be localized by MPR reconstruction of unsubtracted mask run, by putting the three bony landmarks including optic strut, tuberculum sellae and inferior root of anterior clinoid process in the single plane of MPR reconstruction (Fig. 2). The dural ring is point where the ascending ICA enters into subarachnoid space, and consists of proximal and distal dural rings. The dural ring is surrounded on three sides by bony structures: the anterior clinoid process laterally, the optic strut anteriorly, and the tuberculum sellae medially $(2,7,13)$. There is no bony structure posteriorly, while the dura mater continues to the diaphragm sellae and posterior clinoid process (2). The dural ring consists of 2 fibrous rings: DDR arising from fibers of the superficial dural layer and proximal ring related to the deep dural layer which forms the superior border of the cavernous sinus. The DDR forms a complete ring around the ICA and fuses with its adventitia, firmly adherent to the dorsolateral aspect of ICA, but is redundant and forms a pouch (carotid cave) on the ventromedial side.

The origin of ophthalmic artery is often used as the angiographic landmark between the intra- and supracavernous ICA (4), but its origin is variable and extradural or distal intradural origins are not infrequent $(1,14,15)$. Relation between the paraclinoid ICA and adjacent bony structures can be evaluated by $\mathrm{CT}$ angiography (5-7), but it has limitation in case with atheroma, calcifications and a large paraclinoid aneurysm (7). With the 3D DRA and dual volume visualization technique, MPR image of unsubtracted mask volume and VR reconstruction image of subtracted angiography can be fused and displayed in the single task window. Therefore, fusion images of virtual DDR plane displayed as MPR reconstruction image and angiographic image of ICA as VR reconstruction image can be generated and interactively evaluated in the single task window, without artifacts from atheroma or calcification.

Watanabe et al. (12) suggested that fusion images with 3D-cisternography and MR angiography yielded clear visualization of the boundary between the suprasellar cistern and cavernous sinus to locate the DDR. Although precise localization of DDR can be achieved by the fusion of images of these two MR sequences, it needs additional time and costs. 3DRA in our protocol, however, has been acquired within 12 seconds and dual volume visualization was generated on workstation in 3 minutes. Therefore, 3DRA with dual volume visualization technique takes less postprocessing time and the images are with less motion artifact.

DDR is the anatomic landmark between the extradural and intradural location of the ICA. Discrimination of the paraclinoid intradural and extradural ICA aneurysm is critical when considering the treatment options. In the study with 20 sides of cadaver specimens with lateral radiographs, Oikawa et al. (2) proposed the tuberculum sella as the marker of the medial side of the dural ring, which is more proximal than the lateral. They also suggested that the plane of the dural ring inclines in the posteromedial direction; medial inclination at 14 to $31^{\circ}$ (mean 21.8 ${ }^{\circ}$ ) against the horizontal line in the anteroposterior view on radiographic studies, and posterior inclination at 5 to $43^{\circ}$ (mean $20.3^{\circ}$ ) against the planum sphenoidale in the lateral projection. In our series, the medial inclination ranged at 8 to $43^{\circ}$ (mean $17.4^{\circ}$ ), and posterior inclination angle at -2 to $20^{\circ}$ (mean $6.4^{\circ}$ ). Large ranges in angles of medial and posterior inclination in these two studies suggest that individual variation of inclination angle is too frequent that mean value of these inclination angles could not be solely used for estimation of DDR plane.

3DRA with dual volume visualization is easy to apply and interpret because it provides real-time interactive functions such as changing the window setting, sliding and rotation of the two volumes together or separately. With this simple postprocessing 


\section{Distal Dural Ring and Paraclinoid Carotid Artery Aneurysms}

technique, we also think that the localization of the virtual DDR plane in relation to the ICA and ophthalmic artery could be easily reproducible.

A limitation of our study was that the findings on 3DRA with dual volume visualization could not be compared with the surgical finding or other methods including high resolution MR. Another potential difficulty of this technique is the localization of a small carotid cave aneurysm along the medial or posteromedial aspect of the DDR, because subarachnoid recess could not be imaged by our technique.

In conclusion, visualization of virtual plane of DDR localized by bony landmarks, and localization of the paraclinoid ICA aneurysm in relation to the virtual plane of DDR is feasible with 3DRA and dual volume visualization.

\section{References}

1. Kim JM, Romano A, Sanan A, van Loveren HR, Keller JT. Microsurgical anatomic features and nomenclature of the paraclinoid region. Neurosurgery 2000;46:670-680; discussion 680-672

2. Oikawa S, Kyoshima K, Kobayashi S. Surgical anatomy of the juxta-dural ring area. J Neurosurg 1998;89:250-254

3. Seoane E, Rhoton AL, Jr., de Oliveira E. Microsurgical anatomy of the dural collar (carotid collar) and rings around the clinoid segment of the internal carotid artery. Neurosurgery 1998;42:869884

4. Punt J. Some observations on aneurysms of the proximal internal carotid artery. J Neurosurg 1979;51:151-154

5. Gonzalez LF, Walker MT, Zabramski JM, Partovi S, Wallace RC, Spetzler RF. Distinction between paraclinoid and cavernous sinus aneurysms with computed tomographic angiography. Neurosurgery 2003;52:1131-1137

6. Hashimoto K, Nozaki K, Hashimoto N. Optic strut as a radiographic landmark in evaluating neck location of a paraclinoid aneurysm. Neurosurgery 2006;59:880-895

7. Murayama Y, Sakurama K, Satoh K, Nagahiro S. Identification of the carotid artery dural ring by using three-dimensional computerized tomography angiography. Technical note. J Neurosurg 2001;95:533-536

8. Hirai T, Kai Y, Morioka M, Yano S, Kitajima M, Fukuoka H, et al. Differentiation between paraclinoid and cavernous sinus aneurysms with contrast-enhanced 3D constructive interference in steady- state MR imaging. AJNR Am J Neuroradiol 2008;29:130133

9. Thines L, Gauvrit JY, Leclerc X, Le Gars D, Delmaire C, Pruvo JP, et al. Usefulness of MR imaging for the assessment of nonophthalmic paraclinoid aneurysms. AJNR Am J Neuroradiol 2008;29: 125-129

10. Thines L, Lee SK, Dehdashti AR, Agid R, Willinsky RA, Wallace $\mathrm{CM}$, et al. Direct imaging of the distal dural ring and paraclinoid internal carotid artery aneurysms with high-resolution T2 turbospin echo technique at 3-T magnetic resonance imaging. Neurosurgery 2009;64:1059-1064

11. Tsuboi T, Tokunaga K, Shingo T, Itoh T, Mandai S, Kinugasa K, et al. Differentiation between intradural and extradural locations of juxta-dural ring aneurysms by using contrast-enhanced 3dimensional time-of-flight magnetic resonance angiography. Surg Neurol 2007;67:381-387

12. Watanabe Y, Nakazawa T, Yamada N, Higashi M, Hishikawa T, Miyamoto S, et al. Identification of the distal dural ring with use of fusion images with 3D-MR cisternography and MR angiography: application to paraclinoid aneurysms. AJNR Am J Neuroradiol 2009;30:845-850

13. Taptas JN. Intradural and extradural ICA. J Neurosurg 1979;51:877-878

14. Beretta F, Sepahi AN, Zuccarello M, Tomsick TA, Keller JT. Radiographic imaging of the distal dural ring for determining the intradural or extradural location of aneurysms. Skull Base 2005; $15: 253-261$

15. Kyoshima K, Oikawa S, Kobayashi S. Interdural origin of the ophthalmic artery at the dural ring of the internal carotid artery. Report of two cases. J Neurosurg 2000;92:488-489 


\title{
삼차원 회전 혈관조영술을 이용한 말단경막교리 및 침대돌기주변 내경동맥동맥류의 평가
}

\author{
${ }^{1}$ 제주한라병원 신경외과 \\ ${ }^{2}$ 가톨릭대학교 의과대학 방사선과학교실 \\ ${ }^{3}$ 인하대학교병원 신경외과 \\ ${ }^{4}$ 가톨릭대학교 의과대학 신경외과학교실
}

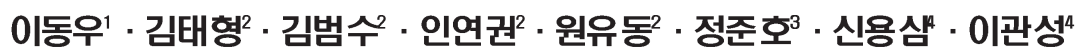

목적: 말단경막고리는 침대돌기주변 내경동맥 동맥류의 경막내외 위치를 구별하는 데 중요한 해부학적 지표이다. 본 연구에서는 침대돌기주변 내경동맥 동맥류를 지닌 환자에서 삼차원 회전(3D) 혈관조영술에서 골지표를 이용한 말단경막고리의 위치를 확인함이 가능한지 알아보고자 하였다.

대상 및 방법: 16 예의 동맥류의 $3 \mathrm{D}$ 혈관조영술을 후향적으로 분석하였다. 영상분석을 위한 워크스테이션에서, $3 \mathrm{D}$ 혈관조영술의 마스크영상으로부터 앞침대돌기, 안장결절, 시신경공버티목의 세 골지표를 기준으로 말 단경막고리의 모의 영상절편을 재구성하였고, 이를 감산혈관조영의 용적묘사 영상과 합성하였다. 접형골 평면을 기준으로 말단경막고리의 모의 평면의 내측 및 후측 기울기를 측정하였다. 침대돌기주변의 내경동 맥 동맥류를 말단경막고리 모의 평면을 기준으로 경막내, 경막경유, 경막외로 분류하였다.

결과: 모든 증례에서 30 혈관조영술의 마스크영상으로부터 말단경막고리의 모의 평면을 재구성할 수 있었고, 이 를 이용하여 침대돌기주변 내경동맥 동맥류와의 위치 관계를 평가할 수 있었다. 말단경막고리의 모의 평면 을 기준으로 한 동맥류의 위치는 경막내 8 예, 경막경유 6 예, 경막외 2 예였다. 모의평면의 내측기울기는 8 $43^{\circ}$ (평균 $17.4^{\circ}$ ) 였고, 후측 기울기는 $-2 \sim 20^{\circ}$ (평균 $6.4^{\circ}$ ) 였다.

결론: $3 \mathrm{D}$ 혈관조영술에서 모의 평면 재구성과 감산혈관조영 용적묘사 영상과의 이중용적 표현을 통해 골지표를 기준으로 침대돌기주변 내경동맥 동맥류와 말단경막고리의 모의평면과의 위치 관계를 평가할 수 있었다.

Key Words : Distal Dural Ring; Paraclinoid Aneurysm; 3D Rotational Angiography 